\title{
Current and future challenges for a long and healthy working life
}

\author{
Richard Peter · Angela Rauch $\cdot$ Olaf Struck $\cdot$ Anita Tisch
}

(C) Institut für Arbeitsmarkt- und Berufsforschung 2015

In the upcoming decades the German working population will shrink and age with some major impacts for the social security systems. As a consequence, policy makers want to increase labour market participation among individuals of higher working age. Although older individuals' labour force participation rates have increased during recent years, their participation rates are still lower than those of all other working age groups. Persistently low participation rates can be found among men and women aged 60 years and older.

It is largely unknown whether and to what extent older workers are particularly affected by the organizational changes in working life. Potential work stress factors are increasing and may have an impact on labour participation of individuals. Examples include growing job insecurity, an increased pace of work, the demand for increasing personal responsibility and flexibility of the workforce. Also, workloads of specific occupational groups may become particular challenges for older workers. Otherwise, organisational changes of the recent past also offer the opportunity of a

R. Peter $(\bowtie)$

Universität Ulm,

Ulm, Germany

e-mail: richard.peter@uni-ulm.de

\section{A. Rauch · A. Tisch}

Institute for Employment Research,

Nürnberg, Germany

e-mail: angela.rauch@iab.de

A. Tisch

e-mail: anita.tisch@iab.de

O. Struck

Otto-Friedrich-Universität Bamberg,

Bamberg, Germany

e-mail: olaf.struck@uni-bamberg.de more flexible active role in the labour market and increase participation in general.

Here, risks and challenges are not distributed equally across the older work force. Some persons are especially affected by particular workloads and leave the labour market relatively young. Others want to participate in the labour market even after the statutory retirement age, or need to continue working, e.g. for financial reasons. Against this background the workshop "Ageing in labour participation. Current and future challenges for a long working life" discussed different challenges older individuals face on the labour market as well as particular approaches to increase labour market participation of older workers. The workshop took place in Nuremberg in October 2012 and was hosted by the Institute for Employment Research (IAB) and the lidA study group. The lidA study group, a cooperation between the Universities of Wuppertal, Ulm and Magdeburg, the IAB, the Institute for Applied Social Sciences (infas) and the Federal Institute for Occupational Safety and Health (BAuA) set up the "lidA Cohort Study - German Cohort Study on Work, Age, Health and Work Participation" to investigate the effects of work and work context on the physical and psychological health of the ageing workforce in Germany. The articles in this special issue combine a sample of papers presenting results gained from the lidA study and papers presented at the workshop.

In the first contribution to this issue, Rauch, Burghardt, Eggs, Tisch and Tophoven ("lidA - leben in der Arbeit. German Cohort Study on Work, Age and Health") give an overview of the content of the lidA study, discuss the aims and the design of the study and provide information on data access and research opportunities.

Frerichs ("Demographischer Wandel in der Erwerbsarbeit - Risiken und Potentiale alternder Belegschaften") discusses the influence of working conditions on age-specific 
workability and labour market participation. He presents potentials and risks of human resource strategies on the company level, while he regards companies as production regimes. The importance of a longitudinal perspective in human resource management is emphasised as well as an actor centred perspective.

Weigl, Müller, Hornung, Leidenberger and Heiden ("Job resources and work engagement: the contributing role of selection, optimization and compensation strategies at work") are using the life-span model of selection, optimization and compensation (SOC) to investigate direct and indirect effects of SOC strategies at work and job resources in predicting work engagement. Based on data collected from a flight attendants study, they show that these strategies are positively associated with work engagement. Therefore favourable conditions of work are essential for successful ageing in the workplace.

Tisch ("Health, work ability and work motivation: determinants of labour market exit among German employees born in 1959 and 1965") analyses early labour market exits employing data from the lidA study. Linking lidA data to register data from the Federal Employment Agency, she empirically tests the hypothesis that work motivation and work ability mediate the relationship between health and labour market exit. Her findings show that men and women have an increased probability of labour market withdrawal when they report health impairments, low work ability or low work motivation. Furthermore, low work motivation and low self-perceived work ability partly mediate the relationship between impaired health and labour market withdrawal.

Tophoven, du Prel, Peter and Kretschmer ("Working in gender-dominated occupations and depressive symptoms: findings from the two age cohorts of the lidA study") are using the lidA data to analyse whether there are correlations between working in male-dominated occupations for women and working in female-dominated occupations for men on one hand and depressive symptoms on the other hand independently from other factors like work stress and work-family conflict. Results indicate that women in maledominated occupations show higher levels of depressive symptoms. Additionally work stress and work-family conflicts are significantly related to depressive symptoms.

Weber and Weber ("Älter, hörbeeinträchtigt und... erwerbstätig!") are presenting results of a project, which studies the effect legislation has had on the professional integration of the hard-of-hearing, those who have lost their hearing and deaf people (GINKO). They show that despite a comprehensive legal framework, only a small amount of prevention measures prescribed by law are implemented at work places of older workers.

Richard Peter is social scientist and Professor of Medical Sociology at the Institute for the History, Philosophy and Ethics of Medicine, Ulm University, Germany. He is one of the PIs of the lidA study. His research focusses on social inequality in health and on work stress, particularly in ageing work forces.

Angela Rauch is a sociologist and researcher in the Department "Joblessness and Social Inclusion" at the Institute for Employment Research (IAB) in Nuremberg, Germany. Her main research interests include labour market of severely disabled persons, occupational rehabilitation of persons with disabilities, the relationship between labour market and health of older work force.

Prof. Dr. Olaf Struck is Professor of Labor Studies at the OttoFriedrich-University of Bamberg. He is head of the Pillar 2 "Learning Environments" in the National Education Panel Study (NEPS) and on the board of the "German Association for Labour Market Research". Research interests: empirical labor market research, human resource management, further education and lifelong learning.

Anita Tisch studied sociology at the University of Bamberg (diploma) and earned a M.Sc. in Gerontology at the University of Southampton. Since 2009 she is working at the Institute for Employment Research (IAB) as a researcher. Her main research interests are the ageing work force, politics of employability and labour market and health. 